\title{
School Libraries across Cultures
}

\author{
Helen Boelens \\ ENSIL Foundation, The Netherlands.
}

Henk van Dam, Senior Project Officer

Royal Tropical Institute, KIT Information \& Library Services, Amsterdam, The

Netherlands.

\author{
Anthony Tilke, Head of Library \\ International School of Amsterdam, Amsterdam, The Netherlands.
}

\begin{abstract}
Migration and globalization throughout the world have caused many schools to become multicultural (or intercultural) institutions where students from more than 40 nationalities, who speak many different languages, receive their education under one roof. Some come from families who have lived in that country for generations and speak the official, national language; others represent small, indigenous groups; others are recent immigrants, including those who are more transient, sometimes called 'Third Culture Kids' or global migrants. All these students use the same learning spaces at school as other students, including the school library. Furthermore, bilingual (secondary) education is being encouraged by a number of national governments. Its goal is to increase students' proficiency in a "world language" and to provide them with an international orientation. Multicultural situations within the school also impact school libraries which need to become multicultural learning environments providing library services at a multicultural level.
\end{abstract}

\section{Introduction}

This paper invites school librarians to think about issues such as "diversity" and "difference" in multicultural situations and asks them to think about how these topics impact the school library. In encourages the development of international-mindedness in school libraries at international level.

It also describes an attempt by the ENSIL Foundation, the Royal Tropical Institute (KIT) in Amsterdam and the International School of Amsterdam to find some solutions to problems confronting school libraries across cultures. The suggestions which appear below 
apply not only to school libraries in developed, perhaps more prosperous countries, but also on those which are located in emerging and developing countries.

This paper will look at this subject from a number of different perspectives:

- Some simple definitions and historical background information about multicultural (or intercultural) education and its objectives will be provided.

- The need for multicultural academic and school libraries will be discussed and some suggestions will be made towards this end.

- The cost of an adequate, multilingual collection plus the training of librarians, especially in developing countries, present difficulties. Some recent attempts to resolve these problems will be described.

- The development of multicultural school libraries in international schools, which usually have good resources and trained personnel, will be described. Opportunities, problems and challenges which need to be met will be identified.

The paper also discusses opportunities, problems and challenges which need to be identified and describes:

- The school library as a multicultural learning environment within the school community;

- literacy skills of immigrant (school) populations which are causing concern;

- literacy instruction in multicultural settings;

- contributions which can be made by school libraries in order to alleviate these problems;

- the development of (online) professional development programs for librarians, to provide them with the necessary expertise to work within a multicultural school environment.

\section{Some Simple Definitions}

Globalization. Often, the situations which are confronting school libraries across cultures are due to globalization, which refers to the process or processes of international integration ... all those processes by which the peoples of the world are incorporated into a single world society, global society (Albrow 1990, p. 9).

Multicultural education and intercultural education. In order to strengthen democracy, education systems need to take into account the multicultural character of society, and aim at actively contributing to peaceful coexistence and positive interaction between different cultural groups. There have traditionally been two approaches: multicultural education and intercultural education.

The UNESCO Guidelines on Intercultural Education (UNESCO, 2006) describe Intercultural Education as a response to the challenge to provide quality education for all. 
These guidelines are framed within a Human Rights perspective as expressed in the Universal Declaration of Human Rights, Art. 26.2 (1948):

Education shall be directed to the full development of human personality and to the strengthening of respect for human rights and fundamental freedoms. It shall promote understanding, tolerance and friendship among all nations, racial and religious groups, and shall further the activities of the United Nations for the maintenance of peace.

Intercultural education aims to go beyond passive coexistence, to achieve a developing and sustainable way of living together in multicultural societies through the creation of understanding of, respect for and dialogue between the different cultural groups (UNESCO, 2006). It needs to concern the learning environment as a whole and impacts aspects of the educational processes, such as school life and decision making, teacher education and training, curricula, languages of instruction teaching methods and student interactions, and learning materials (UNESCO, 2003). Some clarification is needed in order to explain how intercultural education relates to culture, language, religion, cultural diversity and cultural heritage. According to UNESCO (2006), intercultural education respects the cultural identity of learners through the provision of culturally appropriate and responsive education. It outlines the key issues and interrelationships surrounding intercultural education, as well as its objectives and basic operating principles.

Culture is defined as "all the factors that pattern an individual's ways of thinking, believing, feeling and acting as a member of society (UNESCO, 2006, p. 12). It is a system of values, beliefs and standards which guides people's thoughts, feelings and behavior (Hernandez, 1989). Culture and education are intertwined (UNESCO, 2006, p. 13):

The role of the school is central to the development of society, developing the potential of learners through the transmission of knowledge and the creation of competencies, attitudes and values that empower them for life in society. Yet education is also vital to the survival of culture. Culture cannot exist without continual transmission and enrichment through education.

Culture shapes educational content:

Teachers and learners, curriculum developers, policy makers and community members invest their cultural perspectives and cultural aspirations into what is taught, and how it is conveyed. ... Education is also vital to the survival of culture. As a collective and historical phenomenon, culture cannot exist without continual transmission and enrichment through education, and organized education often aims to achieve this very purpose (p.13). 
Culture and Language. Language is one of the most universal and diverse forms of expression of human culture. It makes the transmission of knowledge, identity and memory possible. Linguistic competencies give access to other cultures and encourage openness to cultural exchange. They also enhance academic achievement (p. 13).

Culture and Religion Religious education can be described as learning about one's own religion or spiritual practices, or learning about other religions or beliefs. Different religions, faiths and attitudes are cross-cultural and internally diverse, as they interact with other cultural practices and values. Classrooms are now not only multicultural, but also often multi-faith (p. 14).

Cultural Diversity has been defined as "the manifold ways in which the cultures of groups and societies find expression (UNESCO 2005). It is also "a manifestation of the diversity of life on earth (UNESCO, 2003).

Cultural Heritage was defined by the World Conference on Cultural Policies as "including the works of its artists, architects, musicians, writers and scientists and also the work of anonymous artists, expressions of people's spirituality, and the body of values which give meaning to life (Adams, 1998).

Multicultural education or "international-mindedness in education" incorporates the idea that all students, from majority or minority cultures - regardless of their gender, social class, ethnic, racial or cultural characteristics - should have an equal opportunity to learn in school (Banks, 1993b, p. 3). It encourages learning about other cultures in order to produce acceptance, or at least tolerance, of these cultures. Multicultural education can also be viewed as a continuous educational reform movement which has as its objective the increase in educational quality and achievement of all students, including those who are immigrants or who come from different ethnic backgrounds (Banks, 1989).

\section{Historical Background}

This paper briefly discusses the historical and social contexts of multicultural education in some regions. It address certain issues and attempts to relate these issues to the school library as a multicultural learning environment and to the work and training of teachers and teacher librarians. Global Constructions of Multicultural Education: Theories and Realities (Grant and Lei, 2001) provides insight into multicultural education which has taken place since the 1950s in a number of different countries at many different levels. It addresses issues such as ethnic, racial, linguistic, religious, gender, disability, political, geographic, age, or socioeconomic diversity in education in various parts of the world, thus making some comparisions possible. 
Multicultural education is not new - some countries have been experiencing the effect of immigration on education since the end of World War II. Some countries have a policy to promote integration and to absorb cultural differences. For example, in Germany, France and the French and Italian-speaking parts of Switzerland a strict policy for multiculturalism has not been formulated. Allemann-Ghionda ( 2001, p. 4) states that "As there is no affirmative policy in favor of multiculturalism, ... there is no way to "force" school authorities and teachers to implement intercultural education ...". She goes on to state that:

Given the absence of affirmative policies to protect and foster the plurality of cultures of migrants in society and in education, the theories of intercultural education developed in the different countries represent attempts to change a mainstream idea of education and of pedagogy that is historically still based on the concept of "one concept, one culture, one language". (Allemann-Ghionda, 2001, p. 5).

Other countries have passed laws which, while favoring integration, also respect the rights of minorities to keep contacts with their cultures and languages of origin. These two principles are followed in recommendations concerning "intercultural education", as well as the curricula of many school systems, in which teachers are encouraged to appreciate the variety of cultures and languages represented by migrant children.

Allemann-Ghionda explains that during the period 1955 - to 1975 , experiences with the education of migrant children were based on the "sink or swim" principle, where the strategy was to teach these children the official language and assimilate them into society as quickly as possible. During the 1970's it became clear that these strategies were not effective (school failure) and was contrary to the rights of minorities to have their cultures and languages respected (Allemann-Ghionda, 2001, p. 5-6).

According to Martin (1975), Australia has seen a whole range of cultural, religious and linguistic encounters at many different levels - in the neighborhood, in the local community, in the workplace and especially in schools. Cahill has described the rise and fall of multicultural education in the Australian Schooling system (Cahill, 2011) and also gives an account of the implementation of a Multicultural Education Program which was introduced 1979, however when it became apparent that this program could not be maintained, it was withdrawn in 1986. The present challenge is described by Cahill (2001, p. 56) as "creating pathways for students, regardless of their background, to become future citizens not only of Australia but also of the world, able to interact inter-culturally across national, religions, ethnic, language and class borders".

\section{The Multicultural School Community}

As mentioned above, schools throughout the world are reporting the diversity of students who are now part of the multicultural school community. Many of these students come from minority groups such as indigenous people, territorial minorities and nomads. 
Others are recent immigrants, who have migrated for a variety of complex reasons - i.e. the children of guest workers, immigrants, refugees and asylum seekers.

A list of three principles have been provided by UNESCO $(2006$, p. 30) to guide the school in its transformation into a multicultural (or intercultural) learning environment. These principles are also applicable to the school library. They are summarized below, however the authors recommend that the referenced UNESCO document be studied in detail.

Principle I Intercultural education respects the cultural identity of the learner through the provision of culturally appropriate and responsive quality education for all.

This principle can be achieved by providing curricula and teaching and learning materials that build upon the diverse systems of knowledge and experiences of the learners; incorporate their histories, knowledge and technologies, value systems and further social, economic and cultural aspirations; introduce the learners to an understanding and an appreciation of their own cultural heritage; aim at developing respect for the learners' cultural identity, language and values; and make use of local resources.

Teaching methods should be developed that are culturally appropriate, use traditional forms of media, such as story-telling, drama, poetry and song, and are based on practical, participatory and contextualized learning techniques that include: activities resulting from collaboration with cultural institutions; study trips and visits to sites and monuments. Also, productive activities that are linked to the community's social, cultural and economic needs should take place. Culturally appropriate methods of assessment should be developed. Also, where possible, the choice of language of instruction should include the mother tongue of the learners.

Appropriate teacher training should aims at familiarizing teachers with the cultural heritage of their country, familiarizing teachers with practical, participatory and contextualized teaching methods, raising awareness of the educational and cultural needs of minority groups, imparting the ability to adapt educational contents, methods and materials to the needs of groups whose cultures diverge from the majority group and facilitating the application of diversity as a tool in the classroom to benefit the learner.

Learning environments should be respectful of cultural diversity. Interaction between the school and the community and the involvement of the learners and / or their communities is part of the educational processes

Principle II Intercultural education provides every learner with the cultural knowledge, attitudes and skills necessary to achieve active and full participation in society.

This principle can be achieved through guaranteeing of equal and equitable opportunities in education via the provision of equal access to all forms of education 
for all cultural groups of the population; the elimination of all forms of discrimination in the education system; the adoption of measures that facilitate the integration in the education system of groups with special cultural needs, such as the children of migrant workers.

Also, learning environments that are non-discriminatory, safe and peaceful should be provided. Curricula and teaching and learning materials should impart knowledge about the history, traditions, language and culture of existing minorities to majority groups.

Appropriate teaching methods that promote the learners' active participation in the education process should be used. In so far as language teaching is concerned, every learner should acquire the capacity to communicate, express himself or herself, listen and engage in dialogue in his or her mother tongue, the official or national language(s) of his or her country of residence and in one or more foreign languages. Appropriate teacher initial education and permanent professional training should also be provided.

Principle III Intercultural Education provides all learners with cultural knowledge, attitudes and skills that enable them to contribute to respect, understanding and solidarity among individuals, ethnic, social, cultural and religious groups and nations.

education.

\section{Third Culture Kids or Global Nomads}

The student population at some schools now includes the children of transient global migrants who are sometimes called 'Third Culture Kids' (TCK), as defined in the early 1950s by the American sociologist and anthropologist Ruth Hill Useem (2012) as "children who accompany their parents into another society". More recently, American sociologist David C. Pollock developed the following description for third culture kids:

A third culture kid is a person who has spent a significant part of his or her developmental years outside the parents' culture. The TCK frequently builds relationships to all of the cultures, while not having full ownership in any. Although elements from each culture may be assimilated into the TCK's life experience, the sense of belonging is in relationship to others of similar background (Pollack and Reken, 2009, p.21-2).

Polack and van Reken (2009) agree that TCKs have been around for a long time - they were the children of missionaries $(66 \%)$ and businessmen $(16 \%)$. However, after World War II, with the increase of international business the composition of international families changed, as follows: missionary $(17 \%)$, business $(16 \%)$, government $(23 \%)$, military $(30 \%)$, 
and "other" (14\%) (Cottrell, 2002). Furthermore, some TCK families migrate for work independently of any organization based in their country of origin.

TCKs tend to have more in common with one another, regardless of nationality, than they do with non-TCKs from their passport country (Hymlö, 2002). They often build social networks amongst themselves and prefer to socialize with other TCKs. They have also been described as being highly accepting of other cultures (Hymlö, 2002).

\section{Literacy and the Importance of Language.}

Literacy is defined as: "the ability and the willingness to use reading and writing to construct meaning from printed text, in ways which meet the requirements of a particular social context" (Au, 1993, p. 20). Au considers the various parts of this definition and their relationship to instruction in multicultural settings: the willingness to use literacy (reading and writing), and the search for meaning from the printed text in a specific social context.

According to $\mathrm{Au}$ (2006), "considerable evidence documents the existence of a gap between the literacy achievements of students of diverse backgrounds and their more privileged peers" (p. 15). This gap is of great concern to educators (Au, 2006) and it is imperative, in this era of globalization, that this gap be closed. Students from diverse cultural backgrounds, who differ from the mainstream students in terms of ethnicity, socioeconomic status and primary language, are entering schools in growing numbers. Evidence shows that while some students from diverse backgrounds may achieve a high score for technical reading in a second language, their assessment for reading comprehension is below the norm. This could be due to their lack of understanding of the social context of the selected text.

Evans (2010) discusses the relationship between family scholarly culture and educational success in 27 different countries, and concludes that the social contexts of students' homes and communities contributes to the students' educational achievement. Teachers and school librarians need to be aware that literacy may take many forms and that while they want to acquaint all students with the basic forms of literacy, as accepted by the school, other forms of literacy may be significant to students who come from diverse backgrounds (p. 26) and may depend on the social contexts of students' homes and communities.

Multiethnic literature, especially culturally conscious works, can be of benefit to all students (Au, 1993), helping students from diverse backgrounds to gain pride and confidence in the experiences of their own ethnic group. It also helps all students to develop an appreciation of other cultures. Au defines multicultural and multiethnic literature (p. 176), providing some guidelines for school librarians who wish to make sure that the collection of the school library has a distinct multicultural orientation. Au explains that multiethnic literature can be used to shape students' values and attitudes towards diversity. She also explores some important issues which are relevant to multiethnic literature, such as diverse perspectives of history, discrimination etc. Culturally conscious literature may present a view of history which is different from the content of a typical social studies textbook. $\mathrm{Au}$ 
suggests that teachers and school librarians may wish to do some background reading in order to better understand certain subjects from diverse perspectives.

The school library staff may approach multicultural literature and also activities in the school library in various ways, for example they may wish to focus on heroes, holidays and other components of a particular culture, using literature to introduce students to the contributions of important people or to special customs. However it could be said that this approach gives students a superficial understanding of their own culture and the culture of others. Attempts should be made to ensure that students develop a deeper understanding of underlying cultural values and historical circumstances.

Language. UNESCO promotes mother tongue-based bilingual or multilingual approaches in education throughout the world - an important factor for inclusion and quality in education. Research shows this has a positive impact on learning and learning outcomes (UNESCO, 2012). This statement may suggest that school libraries should provide information and literature in the languages which are spoken by all students who are part of the school community. The collection should not just reflect a "world language" or the accepted language of the school community. Further discussion of this point will take place below.

TCKs are often multilingual, i.e. they are proficient in their mother tongue as well as the language of teaching and learning. These students will be assisted by a school library collection which has a distinct multicultural orientation and which contains not only information about their country of citizenship but also literature from that country in the national language. Most international TCKs attend international schools where the English language is the norm (Pearce, 2002). Parents of TCKs tend to look for schools which share the education system and language of their country of citizenship, so that upon return to their own society reintegration will be easier. If this form of education is unavailable at international level, families will often choose English-speaking schools for their children.

\section{Bilingual Education and Proficiency in a "World Language"}

Bilingual education involves teaching academic content in two languages, in a native and secondary language with varying amounts of each language used in accordance with the program model (Wikipedia, 2012). Below are a number of different examples of this type of education:

- Education of children from ethnic minorities and other native groups. Education begins in a child's native language (sometimes for a relatively short period) before he or she begins learning a national (or sometimes a "world") language as a second language. The goal is to develop literacy in the child's native language first, and transfer these skills to the second language.

- Education of recent immigrants who speak a language which is different from national language of their "new" country. 
- Programs which are designed to help native and non-native English speakers to become bilingual and biliterate on a "world" language. The student's primary (or native) language can be used as a vehicle to develop literacy skills and acquire academic knowledge.

In an attempt to increase students' international orientation and their proficiency in a "world language", bilingual (secondary) education is also being encouraged by some national governments. Instruction in non-language subjects such as history or biology takes place in a foreign language (usually English), creating the need for appropriate school library collection (European Platform, 2010). This program has two primary aims: to increase students' language proficiency, and to develop an international awareness

- Programs which are designed to preserve minority languages, which are closely connected to religious beliefs and cultures, especially in indigenous cultures.

- Bilingual and trilingual programs at private schools which have a specific religious orientation, e.g. in Arabic or Hebrew.

\section{The Role of School Libraries in Multicultural (or Intercultural) Education}

School libraries throughout the world are becoming multicultural learning environments, supporting students who come from many different countries and who speak a large number of languages. School and teacher librarians can provide support to these students (and to the school community as a whole) in the following ways:

- By investigating the multicultural policies and philosophies of the national governments, related to society and education. This information can then be shared with other members of the school community.

- By discussing the school's curriculum and how it relates to multicultural (and intercultural) education with the school leadership and other teachers.

- By opening discussions with teachers concerning ways in which the school library can assist the teaching staff in the presentation of this curriculum. Librarians work together with the teaching colleagues to increase students' literacy and information literacy skills (in different languages).

- By becoming familiar with the demographics of the school's student body and identify types of multicultural resources that are needed by the library.

- By identify criteria for evaluating and selecting multicultural literature for children and by providing collections in many different languages (in traditional and digital format).

According to Fearer (2003), multicultural literature benefits all children. Children from minority groups more easily learn from literature depicting their own lifestyles, races, linguistic 
backgrounds, religions, and other characteristics with which they identify. Moreover, seeing their own cultures and characteristics in books fosters a sense of self- worth in children from marginalized populations (Agosto 2001a, Agosto 2001b).

Multicultural literature can serve as a mechanism for people to communicate with each other about their differences and similarities, increasing understanding and cooperation (Agosto 2001a, Agosto 2002b).

According to Agosto (2001a), citing Yokota, multicultural school library materials should be selected using the following five criteria: cultural accuracy, rich cultural details, authentic dialogue and relationships, in-depth treatment of cultural members, inclusion of members of minority groups for a specific purpose by:

- providing appropriate collections about students' own cultural heritage. The cultural accuracy and quality of all library materials is most important and should be checked before they are included in the school library.

- making sure that teaching which takes place in the school library places a strong emphasis on multicultural (intercultural) education;

- developing tools that can be used to select resources which are appropriate for a multicultural school library and to use these tools to select resources for one particular cultural group. Some schools approach senior students, teachers and parents to ask them for suitable suggestions. Others ask school library colleagues for suggestions, using (international) list-servs. Also, the International Children's Digital Library (http://en.childrenslibrary.org/) can be a good source.

- discussing a budget which will make the provision of these resources possible, using open source materials whenever possible;

- studying questions which arise when looking for solutions for the cataloguing of books and information in languages which library staff does not speak or write. Some school librarians ask senior students who are proficient in their own national language (language of citizenship) and parents for help with cataloguing books in that specific language.

- providing activities, games, etc. in the library which relate to the cultural heritage of all students;

- providing an atmosphere within the library where students who have arrived from another country or territory feel comfortable, know that they are welcome and will receive help from the school library staff;

- helping to bring Third Culture Kids together and by making sure that the school provides them and their patents with some kind of support network. Also, information about TCKs should be made available for students, teachers and parents. 


\section{Some New Ideas for Possible Solutions for Multicultural School Libraries, Especially Those in Developing and Emerging Countries}

The following ideas are presently being addressed by the Royal Tropical Institute in Amsterdam (KIT), the Netherlands and the ENSIL Foundation. Initially, KIT set up an international toolkit for African university libraries which is being used in at number of African universities. It is important to note that the existence of a university library is one of the international criteria for university accreditation and therefore funding became available from international organizations to support the development of these libraries.

After taking into account the information was contained in the IFLA/FAIFE World Reports 2007 and 2010 (Bothma, 2007 and Bothma, 2011), reporting the increasing availability of Internet services in school libraries throughout the world, discussions are now taking place with other organizations and charities regarding the adaption of this toolkit for multicultural (school) libraries in developing and emerging countries. It will provide free online (multilingual, multicultural) collections and training programs for school library staff, including multilingual, multicultural collection development, cataloguing and information literacy instruction, training webinars, etc. Initially, the school library toolkit will be developed in English, however attempts will also be made to translate the toolkit into French and Portuguese at a later date. At this point, funding for the development of this school library toolkit is a problem; different organizations and charities are being approached and being asked to provide financial assistance.

Also multilingual online communication with these libraries, using social networking, internet portals and online databases will provide support to these librarians. KIT is looking into these possibilities and has provided a portal and Facebook page - "Librarianship in the South" - for this purpose. School librarians throughout the world are encouraged to use these facilities and to send information to them for publication.

\section{Conclusions}

This paper attempts to describe multicultural (intercultural) situations in schools throughout the world and provides some insight into the need for multicultural (intercultural) school libraries at many different levels. It also describes actions which the school library staff can take to ensure that the school library becomes a multicultural learning centre providing support to the entire school community. This will increase in the quality of education throughout the school, especially for students from multicultural groups.

\section{References}

Adams, D. (1998). The World of Cultural Polic: A report on UNESCO's World Conference 
on Cultural Policies for Development, Stockholm, March/April 1998.

http://www.wwcd.org/policy/Stockholm.html accessed on 30 May 2012.

Agosto, Denise. 2001a. Bridging the culture gap: ten steps to a more multicultural youth library. Journal of Youth Services in Libraries 4, no. 3 (spring): 38-41.

Agosto, Denise. 2001b. The cultured word: cultural background, bilingualism, and the school library. School Libraries Worldwide 7, no. 1: 46-57.

Albrow, M. and King, E. (eds.) (1990) Globalization, Knowledge and Society: Readings from International Sociology. Thousand Oaks, CA: Sage

Alleman-Ghionda, C. (2001) Sociocultural and Linguistic Diversity, Educational Theory, and the Consequences for Teacher Education: A Comparative Perspective in Global Constructions of Multicultural Education: Theories and Realities, C.A. Grant and J. L. Lei, eds. Malwah, NJ: Routledge.

Au, K.H. (1993). Literacy Instruction in Multicultural Settings. Belmont, CA: Wadsworth/Thomson Learning.

Au, K.H. (2006). Multicultural Issues and Literacy Achievement. Mahwah, NJ: Routledge.

Banks, J.A. and Banks, C. A. (1989). Multicultural Education: Issues and Perspectives. Needham Heights, MA: Allyn and Bacon.

Banks, J.A. (1993a). Multicultural Education: Historical Development, Dimensions, and Practice in Review of Research in Education Vol. 19, pp. 3-49

Banks, J.A. and Banks, C. A. (1993b). 2nd edition. Multicultural Education: Issues and Perspectives. Needham Heights, MA: Allyn and Bacon.

Bothma, T. J. (ed.) (2007) IFLA/FAIFE World Report Series, Vol. VII, IFLA World Report 2007. Accessed on May 30, 2012, from IFLA (International Federation of Library Associations and Institutions): http://www.ifla.org/en/faife/the-world-report-2007-toc

Bothma, T. J. (ed.) (2011) IFLA/FAIFE World Report Series, Vol. VIII, IFLA World Report 2010. Accessed on September 30, 2011, from IFLA (International Federation of Library Associations and Institutions): http://www.ifla-world-report.org/files/uploaded/ifla wr/IFLA-WR-2010-Analysisand-Conclusions.pdf

Cahill, D. (2001). The Rise and Fall of Multicultural Education in the Australian Schooling 
System in Global Constructions of Multicultural Education: Theories and Realities, C.A. Grant and J. L. Lei, eds. Malwah, NJ: Routledge.

Cottrell, Ann (2002). Educational and Occupational Choices of American Adult Third Culture Kids in 'Military Brats and Other Global Nomads', M. Ender, ed. Wesport, CT: Greenwood Press.

Ender, M. G. (ed.) (2002). Military Brats and Other Global Nomads: Growing Up in Organization Families. Wesport, CT: Greenwood Press.

Europees Platform (European Platform) (2010). A sustainable advantage: The findings of a study into bilingual education. Haarlem, The Netherlands: European Platform www.tweetaligonderwijs.nl accessed on 30 May 2012.

Evans, M.D.R. et al. (2010). Family scholarly culture and educational success: Books and schooling in 27 nations. Reno: Sociology Department, University of Nevada.

Fearer, K (2003). First Place School: Acquisition of Multicultural Resources http://students.washington.edu/aliss/silverfish/archive/april2003/fearer.pdf accessed on 30 May 2012.

Grant, C.A. and Lei, J. L. (2001). Global Constructions of Multicultural Education: Theories and Realities Malwah, NJ: Routledge.

Hernandez, H. (1989). Multicultural Education: A Teacher's Guide to Content and Process. Colombus, OH: Merrill.

Hymlö, Annika (2002). 'Other' Expatriate Adolescents: A Postmodern approach to Understanding Expatriate Adolescents among non-U.S. Children in 'Military Brats and Other Global Nomads', M. Ender, ed. Wesport, CT: Greenwood Press. p. 230.

Martin, J. (1975). The education of migrant children in Australia 1945 - 1975. In Australian Immigration: A bibliography and digest (pp. 1 - 65) C. Price \& J. Martin (Eds.). Canberra: Australian National University.

Pearce, Richard (2002). Children's International Relocation and Development Process in 'Military Brats and Other Global Nomads', M. Ender, ed. Wesport, CT: Greenwood Press. pp. 157, 168-170..

Pollock, D.C. and Reken, R. van (2009). Third Culture Kids: The Experience of Growing Up Among Worlds, 2nd edition Boston. MA: Nicholas Brealey. 
UNESCO (2003) : Education in a Multilingual World, UNESCO Education Position Paper. Paris: UNESCO. http://unesdoc.unesco.org/images/0012/001297/129728e.pdf accessed on 30 May 2012.

UNESCO (2003): Sharing a World of Difference: The Earth's Linguistic, Cultural and Biological Diversity. Paris, UNESCO

UNESCO, 2005. Convention on the Protection and Promotion of the Diversity of Cultural Expressions , Article 4.1

http://portal.unesco.org/en/ev.php-

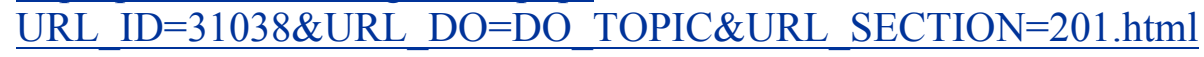
accessed on 30 May 2012.

UNESCO, 2006. UNESCO Guidelines on Intercultural Education, Paris: UNESCO http://unesdoc.unesco.org/images/0014/001478/147878e.pdf accessed on 30 May 2012.

UNESCO, 2012. Languages in Education: Mother Tongue Multilingual Education. http://www.unesco.org/new/en/education/themes/strengthening-education-systems/languagesin-education/ accessed on 30 May 2012.

United Nations (1948). Universal Declaration of Human Rights, Art. 26.2, http://www.wunrn.com/reference/pdf/univ dec hum right.pdf accessed on 30 May 2012.

Useem, Ruth H. (2012) Third Culture Kids: Focus of Major Study. Article 1. TCKWorld. http://www.tckworld.com/useem/art1.html accessed on 30 May 2012.

Wikipedia, 2012. Bilingual education. http://en.wikipedia.org/wiki/Bilingual education Accessed on 30 May 2012. 